\title{
COOPERATION TO ACHIEVE SUCCESSFUL TOURISM
}

\section{Ágnes VIRÁG}

Szent Istvan University, Faculty of Economics and Social Sciences, Gödöllő, Hungary

\begin{abstract}
Tourism has become one the most quickly developing economic sectors. The creation of sustainable and competitive tourism can be observed and initiated all over the world, so the formation of Tourism Destination Management (TDM) system has become an important way of development worldwide. All over the world there are lots of successful TDM systems, so we have to work hard to achieve success in our homeland as well. I think that a new tourism development concept has positive effects on the development of domestic tourism. The tourism sector may expand more dynamically with cooperation of the players. The institutional development is useful, but the organizations must be established in harmony with the characteristics of each destination and need to represent the interests of the participants. In my research, l examine the development of the Hungarian Tourism Destination Management system, the use of the funds, and the context between TDM funds and infrastructural development. Finally, I intend to present good practices which can be adapted to other tourist destinations, so that everyone can benefit from the Hungarian tourism sector.
\end{abstract}

Keywords: destination, TDM Organization, cooperation, competitiveness, TDM tenders

\section{Introduction}

A serious emphasis is put on the continuous development of tourism in increasingly more countries of the world, which does not only mean increasing number of guests and guest nights, increasing incomes and more accommodation, but it is also necessary to focus on restructuring the tourism system in accordance with the needs of our age. In the early 2000s, Tourism Destination Management (TDM) system appeared among the tourism development opportunities in our homeland. Basic principles of the bottomup approach system are partnership, professionalism and support of financial background.

The advantage of the development concept is that stakeholders may get a role in the future shaping of the tourism sector. In Hungary, the creation of TDM system received increasing attention; the new institution structure was/is built by the cooperation of tourism profession and stakeholders in the last 10 years. There are lots of development areas, but some domestic examples show that Hungarian tourism is going the right direction.

\section{Material and methods}

The word, destination has Latin origin and from tourism point of view, it can be interpreted as the (ordained) end-point of a journey. Tourism destination management (TDM) is a long term, voluntary and organized co-operation of partners (local governments, professional and civilian organizations, businesses) who manage the products and services of the destination as a complex unit with the aim to optimize experiences of tourists and effects resulting in tourism activities, taking into account criteria of sustainability (Víg, 2010). The aim is to achieve sustainable and competitive tourism.

Stakeholders of tourism have to face a number of challenges including competitiveness, quality requirements, infrastructural requirements, and changes in tourism trends. Service providers need to have a versatile but unique offer on the global market, if they are to persuade the tourists to choose attractions of a particular area. Also, there are new quality demands from tourists to be met. A special emphasis is to be given to the development of tourism infrastructure. Furthermore, trends have to be taken into consideration, because needs of present day tourists can only be met by offering complex programs and tourism experiences. The creation of Tourism Destination Management system which guarantees that tourism is controlled and managed by competent professionals, and local communities can be an adequate answer to these challenges.

Modern tourism destination management is based on several elements (Nyirádi and Semsei, 2007):

1. Cooperation potential: it is a basic requirement that all the different size service providers, institutions and businesses of the tourism region should establish partner relationships.

2. Service networks: co-operation of services aimed at a target group has to be guaranteed, complex experiences have to be offered from the arrival of the tourists till their departure.

3. Management and marketing competencies: with the involvement of all partners, the destination has to create a strategy that is accepted and considered binding by all members.

4. Technology: proper online information and booking system is required.

5. Professional structure: both qualitative and quantitative factors have to be considered when recruiting personnel for the professional organizations.

6. The tourist's point of view: the destination has to be developed based on the needs of the tourists to make it really competitive.

7. Brand name: to symbolize uniqueness, it is advisable to enter the market with a brand name.

8. Financial background: the operation of organizations depends on the financial stability. The TDM organizations can finance their work from membership fees, entrepreneurial income, various subventions and application sources.

In the following, I will explain how Hungarian TDM system is built and operated and how life of destination organizations was like in the last 10 years. I will reveal theoretical background of the TDM system with the TDM Operational Handbook (edited by Imre Lengyel) and the Balaton TDM booklets. I will analyze professional documents of Hungarian TDM Alliance to see to what extent the organizations could obtain the EU tender resources. From the 
statistics of Hungarian TDM Alliance, I will emphasize the information of TDM tenders and I will analyze the success of TDM tenders in Hungary. I will go into details about a local organization and its competitive work with help of a short presentation, showing it as a good practice. I will reveal the developing activities of a cross-border TDM organization. These organizations prove that it is possible to achieve significant results with the formation of partnership in the tourism sector. While presenting the good practices, I will lean on the websites of organizations and vocational interviews.

\section{Results and discussion}

The TDM system is a hierarchically structured organizational unit, its base is formed by the community-based organizations. The micro-regional alliances unite the local organizations. The regional organizations are made of microregional alliances. The peak of the system is the national organization. The TDM system consists of different levels of organizations (Lengyel, 2008).

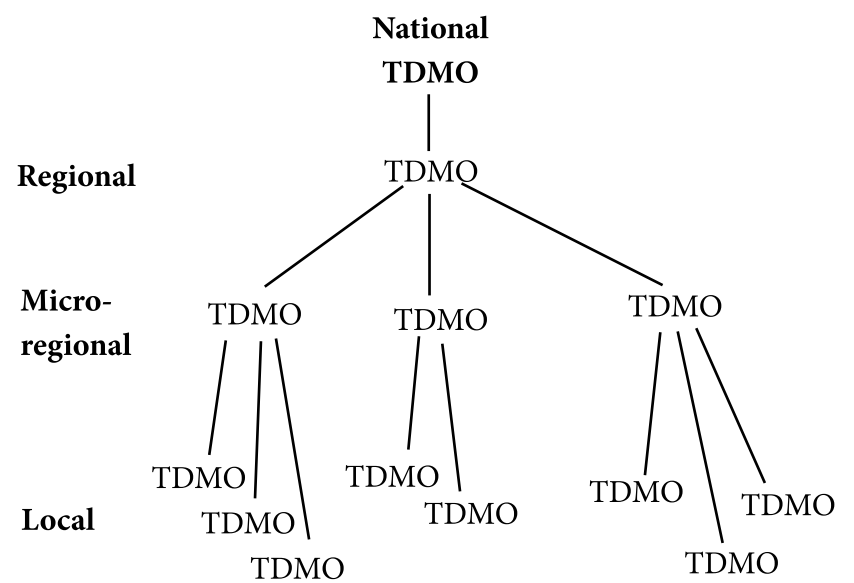

Figure 1 Structure of TDM system in Hungary Sources: own editing, 2013

The reorganization of the tourism institutional system and the creation of the tourism destination management system appeared in our homeland related in relation with. There were mainly Austrian and Italian examples. The National Tourism development Strategy between the years 2005-2013 defined the reorganization of the old institutional system with the formation of local and micro-regional TDM organization and with the transformation of existing national and regional organizations.

The European Union allocated 13 billion Ft to the formation and transformation of TDM organizations in the budgetary period 2007-2013. In Hungary, the first TDM tender appeared in 2008, a call for tender was announced with two occasions until 2013, in 2011 in all regions, in 2012 in all regions with the exception of Central Hungary. The local and micro-regional organizations may have applied for the union support through the regions' operative programs. In 2009, 37 projects won tender support under severe condition system. In 2011, inside the frameworks of the New Széchenyi Plan, the next tender was announced originally with three competitions (May, September, and December). However, the call was suspended, referring to vocational reasons in September 2011. Considerable vocational change did not happen in the tender call nearly in the one year period. In 2012, the tender was restarted with the fraction of the utilizable sources, the withdrawal of the clusters and the exception of Central Hungary Region.

Table 1 summarizes the number of the winners of the three tenders and the measure of the won sources. In 2009, there were 37 successful projects, in 2011 only 32 and in 2012, 23 organizations won the Union support. The first 37 winning organizations received 1,656.4 million Ft support in total, then in 201132 competitors received 1,791.36 million Ft, and the 23 winners of the last tender call were given 1,043.5 million Ft from the EU resources. In 2009, the majority of the winning organizations were from the regions of Northern Hungary, Central Transdanubia and Lake Balaton. In the case of Balato, $n$ there was a separated tender call in Central, Southern and Western Transdanubia regions in three tender periods. In 2011, the number of winning organizations was outstandingly high in Balaton tourism region, where 11 organizations received the Union support. The most of the winning organizations were from the regions of Southern and Central Transdanubia in 2012. In the Southern Great Plain region the lateness - which can be manifested on the more economic sector of reason is, that in 2009 there was no successful organization. In 2011, there were 2 and in 2012 three organizations figured on the application with success. The region of Central Hungary expedient to emphasize, we can see that in 2009 there was 1, in 2011 there were 2 organizations that won union sources, but in 2012 the publication did not provide a tender opportunity already for organizations inside the region (Hungarian TDM Alliance, 2013).

As much as 78 local and 7 micro-regional registered organizations came into existence until September 2013 in our homeland. First regional TDM

Table 1 The number of successful TDM Organizations and the amount of awarded funds on TDM tenders into regions.

\begin{tabular}{|c|c|c|c|c|c|c|}
\hline \multirow[t]{2}{*}{ Area } & \multicolumn{2}{|c|}{ 2009-es ROP TDM tender } & \multicolumn{2}{|c|}{ 2011-es ROP TDM tender } & \multicolumn{2}{|c|}{ 2012-es ROP TDM tender } \\
\hline & $\begin{array}{l}\text { acquired resources in } \\
\text { million Ft }\end{array}$ & $\begin{array}{c}\text { number of supported } \\
\text { projects }\end{array}$ & $\begin{array}{c}\text { acquired resources in } \\
\text { million Ft }\end{array}$ & $\begin{array}{c}\text { number of supported } \\
\text { projects }\end{array}$ & $\begin{array}{l}\text { acquired resources in } \\
\text { million Ft }\end{array}$ & $\begin{array}{c}\text { number of supported } \\
\text { projects }\end{array}$ \\
\hline Northern Hungary & 378 & 11 & 329.14 & 6 & 82.19 & 2 \\
\hline Northern Great Plain & 207.98 & 4 & 42.35 & 1 & 70.44 & 1 \\
\hline Southern Great Plain & 0 & 0 & 141.65 & 2 & 112.41 & 3 \\
\hline Central-Hungary & 49.38 & 1 & 89.93 & 2 & 0 & 0 \\
\hline Central Transdanubia & 355.23 & 8 & 189.63 & 3 & 227.31 & 5 \\
\hline Balaton & 429.98 & 8 & 570.92 & 11 & 192.82 & 4 \\
\hline Western Transdanubia & 54.88 & 1 & 140.64 & 2 & 134.55 & 3 \\
\hline Southern Transdanubia & 180.96 & 4 & 287.08 & 5 & 223.80 & 5 \\
\hline
\end{tabular}




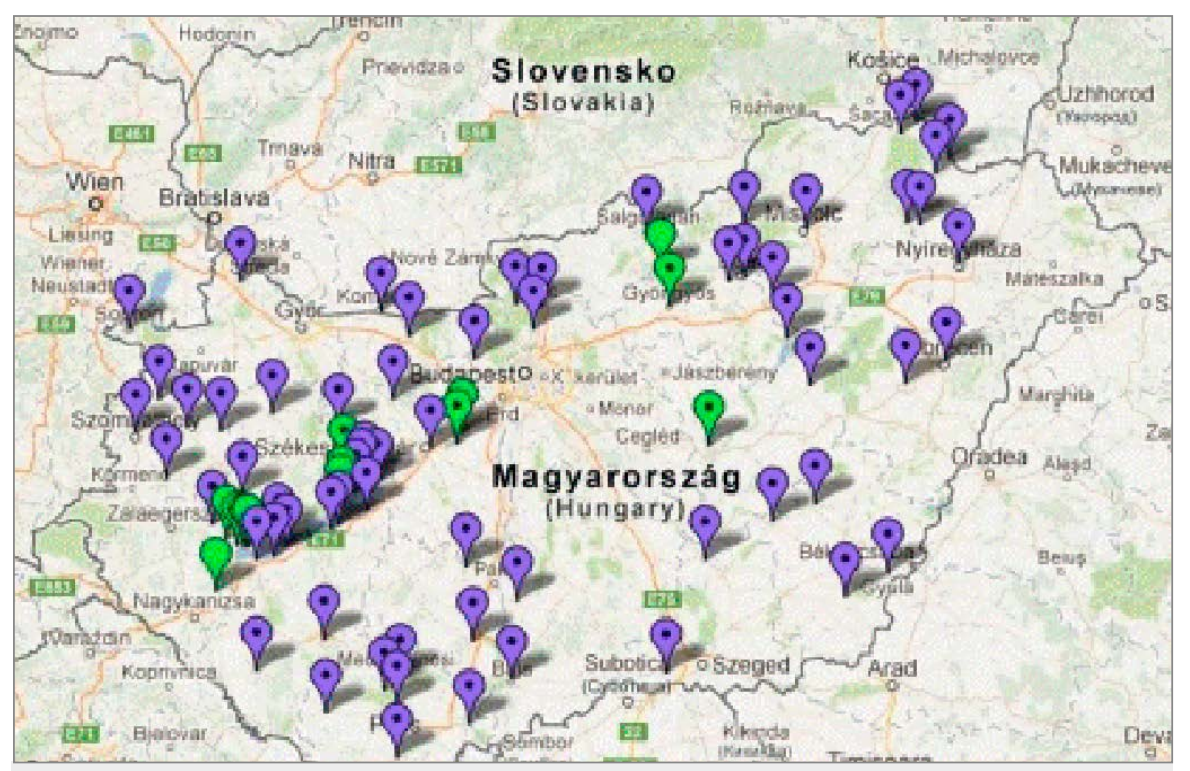

Figure 2 Hungarian TDM Organizations in 2013

Sources: Hungarian TDM Alliance, 2013. Blue: only local TDM Organization. Green: Local and micro-regional TDM Organization is in the areas

organization was born around Balaton in 2011. The Hungarian TDM Alliance inquired in which year they came into existence mostly among the registered TDM organizations. The total of $40 \%$ of the registered TDM organizations took part in the inquiry, thus, complete conclusions may not be drawn. The result shows well the beat of the domestic organization development. Visibly, more organizations came into existence in the tender period. The number of TDM organizations was insignificant before 2005, whereas in 2008-2009 and in 2010-2011, the number of organizations increased continuously. The sustainability of operation of the organizations has been ensured only in short-term. They hope the nascent tourism law will determine the income of tourism tax to return to the TDM organizations and there will be better drawdown opportunities for the tender supports (Hungarian TDM Alliance, 2013).

In Hungary, large differences can be discovered between locations of TDM organizations. The Figure 2 shows that more organizations work in the more developed, western part of the country. Gyenesdiás, which is a good example of TDM organizations, was the first local TDM organization in Hungary. The best hierarchical system took shape around Lake Balaton where 20 local, 3 micro-regional and a regional organization work. The micro-regional and the regional organizations get an increasing emphasis for the formation on other parts of our homeland, but it needs more time.

The number of organizations increased continuously in the last years, the reputation of the system increased despite the fact that the law regulation of the system have not come into existence. The professionals consider it exceptionally important to set up a tourism law which can be passed by everybody. The law would regulate the function, the role and the tasks of TDM organizations. The European Union will provide resources on the modernization of the tourism institutional system in its budgetary period 2014-2020. The TDM organizations can hopefully call the union support down in a bigger proportion than in the period of 2007-2013. In this budgetary period, altogether 11.148 billion Ft were allocated in the tenders. TDM organizations can call down successfully only 4.49 billion Ft under three tenders, this means $40.28 \%$ utilization. The regional organizations did not take shape, so it was not possible to use the sources for the regional development. Professionals hope that there will be more regional organizations, and they can use union sources for the development in the next budgetary period (Hungarian TDM Alliance, 2013).

The most important tasks of the organization development are sustainability, competitiveness and regional validation. These may work well if all of the given organizations characters take a part in work. In Hungary, several local and micro-regional organizations work which proves that it is possible to achieve a better result with cooperative work on the tourism market. In Hévíz, the Hévíz Tourism Marketing Association was created in 2006, and then the name of local organization was changed to Hévíz TDM Association as a result of an organizational transformation in 2011. The number of members expanded continuously, in 2006 there were
28 founding members. Today, the association has 101 members. The association deals with tenders and with the operation of the local Tourinform Office. In 2010, the association won 44 million Ft support in the first tender. From the source, different programs were executed, such as study tours, infrastructural developments, contributing to the tourism development. The function of organization shows positive results in number of guests and guest nights and in the qualitative and infrastructural improvements. After the first successful tender, the association won support again in December 2011. As much as 103 million Ft is the total cost of second won tender, $78 \%$ of it is total support, so the organization can work on tourism. Expectedly, the project will end in November 2013 (www.heviz.hu). The two successful tenders show that the TDM organizations can give positive results for tourism stakeholders with collaboration and resolute colleagues. The colleagues of association hope that success will crown their future activities.

According to the specialists dealing with the destination management, there are several successful domestic TDM organizations such as Gyenesdiás Tourism Association or GyöngyösMátra Tourism Non-profit Association in local level, the Tokaj-Hegyalja, Taktaköz, Hernádvölgye TDM Organization or West-Balaton Tourism Office Non-profit Ltd. in micro-regional level. The organizational structure which was founded on destination management appeared in the Visegrad countries, too. In Slovakia, there are increasingly more destination organizations next to (besides) clusters in tourism (Michálková, Kojdová and Némethová, 2012). In the EU and in the Visegrad countries, the strengthening of cross-border cooperation is a very important task (Káposzta, Nagy and Ritter, 2012). A cooperation process with the TDM basis started along the Hungarian-Slovak border. The HungarianSlovak Cross-Border Tourism Destination Project began with support of the European Union in Hungary-Slovakia Cross-Border Cooperation Program 2007-2013 (www.mva.hu/husk/). The partnership started in 2009, in order that in the Hungarian and Slovak border zone let a TDM organization come into existence, which help the integrated tourism development in this region. The total of 6 Hungarian and 3 Slovak members initiated the formation of organization. In November 2010, 8 legal entity organizations and 9 natural persons founded the Integrated Tourism Development Association. Many tourism micro- and small enterprises, the tourism service providers, local governments, and other organizations can join the organization. 
The principal aim is the promotion of activities of tourism development, the strengthening of cooperation, the maintenance of partnership in the Hungarian-Slovak border region. The important task is to increase the number of guests, guest nights, coordination of common marketing, formation of common tourism products and packets (Statutes of Integrated Tourism Development Association, 2010). The result is a detailed attractiveness inventory, a common logo, the trilingual website (http:// www.husktour.com/). In the border zone there were several developments financed by the European Union support. The introduction of the HungarianSlovak tourism card is in process under the management of organization. The participants believe that the partnership can help to achieve the dynamic tourism and economic development of this region in the future.

\section{Conclusion}

The HungarianTDM system was builtgradually; the institutional reorganization receives increasing attention. The development of tourism receives increasing attention in National Development Concept and National Area Development Concept 2014-2020, the main aim of the concept is the formation of total TDM system, the creation of accurate legal and law regulation. The TDM organizations have to face several challenges, but the structure based on the partnership shows a positive future vision. Professionals hope that the questions of sustainability of Hungarian TDM organizations will become clearer, the tourism law comes into existence with professional touch, and the different level TDM organizations will be able to retrieve the EU resources successfully in the next budget season. Cooperation is not enough to succeed; participants of tourism have to work together for the successful performance of destinations. The organizational system which is based on the partnership principles develops continuously in the country and in the Visegrad countries as well; the Hungarian-Slovak cooperation is a good example, and some Czech and Polish contacts are becoming stronger in tourism life. In the future, tourism organizations of these countries will have more and more international contacts among themselves, which can help competitiveness of tourism destinations. I think that the TDM development based on cooperation is a good opportunity, with which it is worth living, it is possible to achieve better and more results with collaboration.

\section{References}

LENGYEL, M. (edited). 2008. TDM Operational Handbook. Budapest : Heller Farkas, Budapest, 2008.

NYIRÁDI, Á. - SEMSEI, S. (edited). 2007. Balaton TDM booklets. Lake Balaton Development Coordination Agency, Siófok, 2007.

VÍG, T. 2010. The creation of Tourism Destination Management (TDM) system in Hungary. In: Turizmus Bulletin, 2010. p. 1-2.

THE HUNGARIAN-SLOVAK Cross-Border Tourism Destination Project website. Available from: http://www.mva.hu/husk/ (2013.08.20.)

THE HUNGARIAN-SLOVAK Cross-Border Tourism Destination Organization website. Available from: http://www.husktour.com (2013.08.12.)

MICHÁLKOVÁ, A. - KOJDOVÁ, H. - NÉMETHOVÁ, I. 2012. Impact of Declared Clusters of Tourism on Slovak Destinations. In: Studia commercialla Bratislavensia, 2012, no. 4, pp. 627-639.

KÁPOSZTA, J. - NAGY, H. - RITTER, K. Cross-border cooperations to enhance economic development in the Visegrad countries. In: Delphi Business Review, vol. 11, no. 2, pp. 11-24.

KÁPOSZTA, J. 1998. Területi gazdaságtan. Gödöllő : GATE, 1998. 110 p.

KÁPOSZTA, J. - NAGY, H. 2013. The inherence of the development of the spatial-structure in Hungary. In: $25^{\text {th }}$ IAAE Conference, 15.-17. 6. 2013, Durban. pp. 24-30.

STATUTES of Integrated Tourism Development Association. 2010.

HÉVÍZ TDM Association website. Available from: http://www.heviz.hu (2013. 08. 25.)

PROFESSIONAL documents of Hungarian TDM Alliance. 2013.

\section{Contact address:}

Ágnes Virág, PhD student, Szent Istvan University, Faculty of Economics and Social Sciences, 2100 Gödöllő, Páter K. st. 1., e-mail: virag.agnes@gtk.szie.hu 